Article

\title{
Efficient Degradation of Mordant Blue 9 Using the Fenton-Activated Persulfate System
}

\author{
Md. Nahid Pervez $\left.{ }^{1,2}{ }^{(}\right)$, Felix Y. Telegin ${ }^{3}$, Yingjie Cai ${ }^{1,4, *}$, Dongsheng Xia ${ }^{4}$, Tiziano Zarra ${ }^{2} \mathbb{C}$ \\ and Vincenzo Naddeo $2, * \mathbb{D}$ \\ 1 Hubei Provincial Engineering Laboratory for Clean Production and High Value Utilization of Bio-based \\ Textile Materials, Wuhan Textile University, Wuhan 430200, Hubei, China; nahid.tex92@gmail.com \\ 2 Sanitary Environmental Engineering Division (SEED), Department of Civil Engineering, University of \\ Salerno, via Giovanni Paolo II 132, 84084 Fisciano (SA), Italy; tzarra@unisa.it \\ 3 Department of Inorganic Chemistry, Ivanovo State University of Chemistry and Technology, 7, \\ Sheremetevsky Ave, Ivanovo 153000, Russia; felix.telegin@gmail.com \\ 4 Engineering Research Centre for Clean Production of Textile Dyeing and Printing, Ministry of Education, \\ Wuhan Textile University, Wuhan 430200, Hubei, China; dongsheng_xia@wtu.edu.cn \\ * Correspondence: yingjiecai@wtu.edu.cn (Y.C.); vnaddeo@unisa.it (V.N.); \\ Tel.: +86-(0)-27-59367334 (Y.C.); +39-(0)-89-96-9333 (V.N.)
}

Received: 15 October 2019; Accepted: 26 November 2019; Published: 30 November 2019

\begin{abstract}
In this study, a Fenton-activated persulfate $\left(\mathrm{Fe}^{2+} / \mathrm{PS}\right)$ system was introduced for the efficient degradation of Mordant Blue 9 (MB 9) as a textile dye in an aqueous solution. Results showed that the degradation of MB 9 was markedly influenced by operational parameters, such as initial $\mathrm{pH}, \mathrm{PS}$ concentration, $\mathrm{Fe}^{2+}$ concentration, and initial dye concentration. Optimal reaction conditions were then determined. Inorganic anions, such as $\mathrm{Cl}^{-}$and $\mathrm{HCO}_{3}{ }^{-}$, enhanced the degradation efficiency of MB 9 under optimal conditions. Addition of $\mathrm{HCO}_{3}{ }^{-}$reduced the degradation performance of MB 9 , whereas the addition of $\mathrm{Cl}^{-}$increased the degradation percentage of $\mathrm{MB}$ 9. In addition, quenching experiments were conducted using methanol and tert-butyl alcohol as scavengers, and methanol was identified as an effective scavenger. Thus, the degradation of $\mathrm{MB} 9$ was attributed to $\mathrm{SO}_{4}^{--}$and - $\mathrm{OH}$ radicals. The degradation and mineralization efficiency of MB 9 was significantly reduced using the conventional Fenton process i.e., $\mathrm{Fe}^{2+} /$ hydrogen peroxide (HP) because of the formation of a Fe complex during degradation. Meanwhile, the $\mathrm{Fe}^{2+}$ /persulfate (PS) system improved the degradation and mineralization performance.
\end{abstract}

Keywords: Fenton-activated; Fe-complex; persulfate; mordant dyes; scavengers

\section{Introduction}

Dyes have prompted serious widespread concern because of their substantial contribution to water pollution. The presence of these colorants in effluents not only deteriorates water aesthetically but also harms the social system and health; moreover, these colorants present a threat to environmental sustainability [1-3]. Mordant dyes derived from acid dyes have been widely used for the coloration of textile fibers, such as wool, silk, polyester, cotton, and some modified cellulose fibers $[4,5]$. During coloration, some transition metal ions are typically used with mordant dyes to form a durable dye-metal complex ligand, which enhances fastness to light and washing in dyed fabrics [6]. However, treatment of these dye effluents before they are discharged to the environment has received significant attention because of the potential adverse effects of dyes [7].

Various technologies have been adopted for the degradation of dyes from wastewater, including advanced oxidation processes (AOPs), adsorption, biological and chemical methods, and the use of 
membrane modules [8-10]. Fenton oxidation-based AOPs are among the most effective processes because of their relative ease of operation, low-cost facility, and high removal efficiency [11,12]. The Fenton process oxidizes organic pollutants using hydroxyl radicals $(\mathrm{HO} \bullet)$, which are generated from the hydrogen peroxide $\left(\mathrm{H}_{2} \mathrm{O}_{2}\right)$-ferrous sulfate reaction in an acidic medium [13]. However, the widespread application of Fenton oxidation is impeded by several constraints, such as the limited $\mathrm{pH}$ range, sludge generation and large consumption of chemicals [14]. In addition, some studies [15-17] have reported that the mordant dye degradation efficiency in Fenton oxidation was inhibited because of the formation of an iron complex with dye ligands. Determining a useful process for the efficient degradation of mordant dyes is desirable and can be a significant step in solving environmental issues.

Persulfate (PS) oxidant has recently been recognized as an essential substitute for hydrogen peroxide (HP) in Fenton processes for the effective removal of pollutants $[18,19]$. PS can be decomposed to produce sulfate radicals $\left(\mathrm{SO}_{4}^{--}\right)$via an activation process that can efficiently remove pollutants from wastewater [20]. $\mathrm{SO}_{4}^{\bullet-}$ possesses higher redox potential and half-life span stability than $\mathrm{HO} \bullet$ [21]. PS activation by transition metal ions $\left(\mathrm{Fe}^{2+}, \mathrm{Co}^{2+}\right.$, etc.) has received particular attention owing to the generation of a significant amount of $\mathrm{SO}_{4}^{\bullet-}$ radicals [22]. Ferrous sulfate $\left(\mathrm{Fe}^{2+}\right)$ is the most widely used PS activator because of its cheap, non-toxic, and high natural abundance compared with other transition metals [23]. As shown in Equation (1), sulfate radicals can be obtained in the presence of $\mathrm{Fe}^{2+}$ ions. Moreover, in the reaction, a stronger oxidant, sulfate radical, is converted to a weaker oxidant, and the hydroxyl radical and both radicals contribute to the degradation, resulting in higher efficiency (Equations (2) and (3)) [24].

$$
\begin{gathered}
\mathrm{Fe}^{2+}+\mathrm{S}_{2} \mathrm{O}_{8}^{2-} \rightarrow \mathrm{Fe}^{3+}+\mathrm{SO}_{4}^{\bullet-}+\mathrm{SO}_{4}^{2-} \\
\mathrm{SO}_{4}^{\bullet-}+\mathrm{H}_{2} \mathrm{O} \rightarrow \mathrm{OH}^{\bullet}+\mathrm{HSO}_{4}^{-} \\
\mathrm{SO}_{4}^{\bullet-}+\mathrm{OH}^{-} \rightarrow \mathrm{OH}^{\bullet}+\mathrm{SO}_{4}^{2-}
\end{gathered}
$$

The degradation of recalcitrant pollutants in wastewater using a $\mathrm{Fe}^{2+} / \mathrm{PS}$ system has been the focus of many previous studies. Rastogi et al. [25] reported that $90 \%$ of polychlorinated biphenyl could be removed within $24 \mathrm{~h}$ by $\mathrm{Fe}(\mathrm{II}) / \mathrm{Fe}(\mathrm{III})$-mediated activation of the PS system. In addition, several contaminants, such as carbamazepine [26], acetaminophen [27], diatrizoate [28], and iohexol [29], could be successfully degraded using the $\mathrm{Fe}^{2+} / \mathrm{PS}$ system. Studies on the degradation of dyes from textile wastewater by using the $\mathrm{Fe}^{2+} / \mathrm{PS}$ system have thus far been rarely investigated. Kusic et al. [30] reported that the degradation efficiency of reactive azo dyes was strongly influenced by the Fe (II)-activated persulfate system. A large amount of Orange G dye could be successfully degraded from aqueous solution by using the iron (II)-activated persulfate system instead of the conventional Fenton's reagent $[30,31]$. However, this study was prompted by a previous report regarding the lack of studies on the degradation of mordant dyes in the presence of the Fenton-activated persulfate system and compared with the conventional Fenton process.

Therefore, the main purpose of the present study is to evaluate the enhancement of Mordant Blue 9 (MB 9) degradation and mineralization efficiency using the Fenton-activated PS system with an innovative approach. The results demonstrated that the inhibition of degradation during the conventional Fenton process could be overcome by the wide-scale application of the Fenton-activated persulfate system. Moreover, the effects of the operational parameters, such as initial MB 9 concentration, initial $\mathrm{pH}$, and oxidant dosage on the degradation efficiency of MB 9 were evaluated to determine the optimal conditions. The results can potentially provide an invaluable resource for MB 9 degradation from wastewater. 


\section{Experimental}

\subsection{Reagents and Materials}

Mordant Blue 9 (MB 9, 50\%) with molecular weight $502.8 \mathrm{~g} \mathrm{~mol}^{-1}$ was obtained from Sigma-Aldrich Co. (St. Louis, Mo, USA). Hydrogen peroxide $\left(\mathrm{H}_{2} \mathrm{O}_{2}\right)$, ferrous sulfate $\left(\mathrm{FeSO}_{4} \cdot 7 \mathrm{H}_{2} \mathrm{O}\right)$, sodium persulfate $\left(\mathrm{Na}_{2} \mathrm{~S}_{2} \mathrm{O}_{8}\right)$, sulfuric acid $\left(\mathrm{H}_{2} \mathrm{SO}_{4}\right)$, and sodium hydroxide $(\mathrm{NaOH})$ were supplied by Aladdin Chemistry Co., Ltd. (Shanghai, China). All selected materials and reagents were used without further purification. Double-distilled water was collected from the analytical chemistry lab of Wuhan Textile University, China.

\subsection{MB 9 Degradation Procedures}

The degradation procedures were conducted in a $100 \mathrm{~mL}$ beaker at a constant temperature of $25^{\circ} \mathrm{C}$. Specific amounts of MB 9 and ferrous sulfate were introduced into the beaker from their stock solution prepared using a preset molar ratio. The initial solution $\mathrm{pH}$ was adjusted using both $0.1 \mathrm{M} \mathrm{H}_{2} \mathrm{SO}_{4}$, and $0.1 \mathrm{M} \mathrm{NaOH}$ whenever required. The reaction was then initiated by adding PS at a predetermined concentration. The final volume of the solution was fixed at $100 \mathrm{~mL}$, and the solution was magnetically stirred (DF-101S, Tianjin Gongxing Experimental Instrument Co., Ltd., Tianjin, China) at $120 \mathrm{rpm}$ for $1 \mathrm{~h}$ to ensure proper mixing. At a specific time interval, $1 \mathrm{~mL}$ of the sample was withdrawn from the reactor. Quenching experiments were immediately started by adding methanol solution, and the solution was filtered using a membrane with a pore size of $0.38 \mu \mathrm{m}$ for further analysis. To degrade MB 9 by using the conventional Fenton process, PS was replaced by hydrogen peroxide under the same aforementioned experimental conditions, and the entire experimental procedure was repeated for verification (Scheme 1).
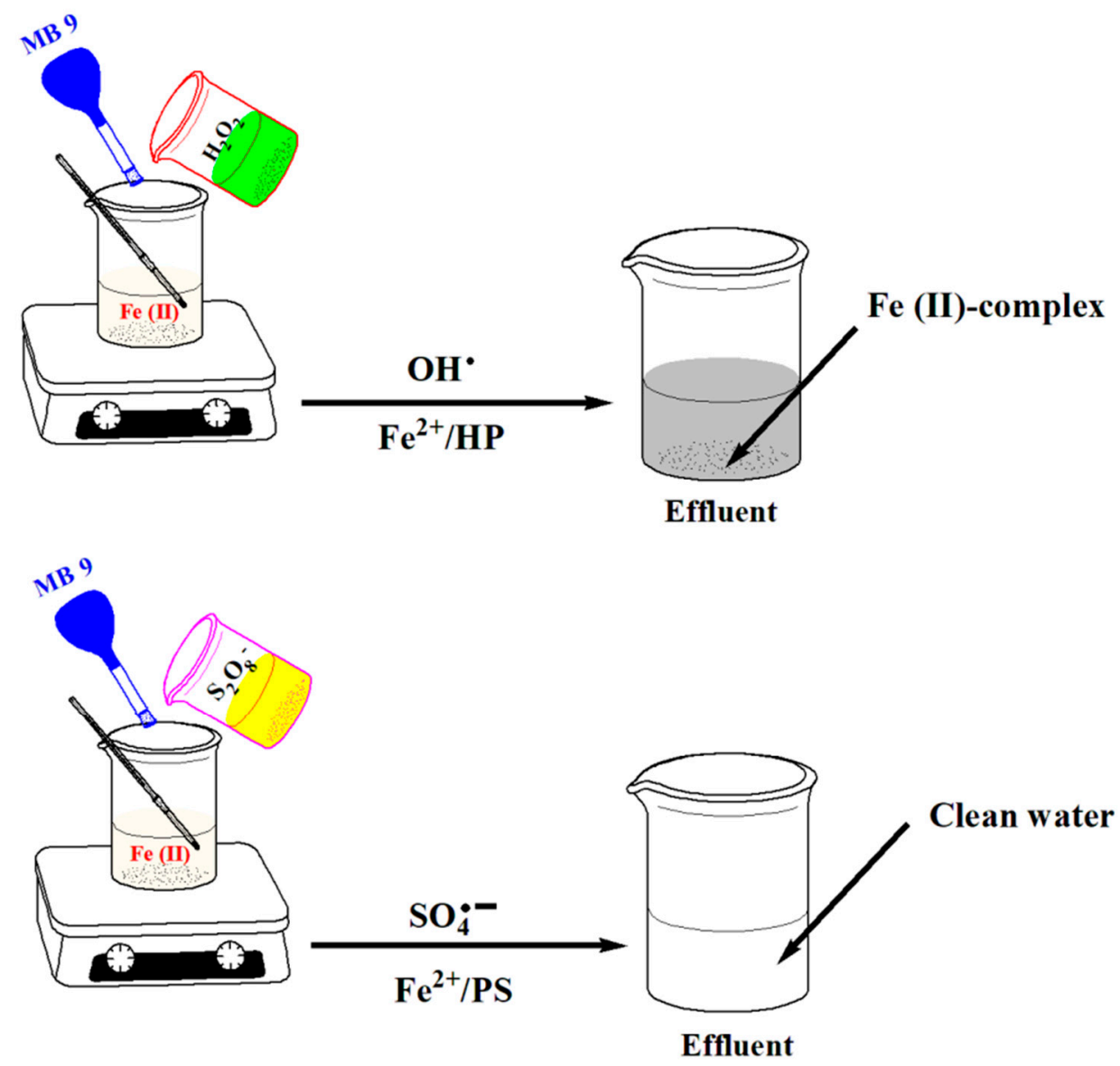

Scheme 1. Experimental setup of Mordant blue 9 degradation in both systems. 


\subsection{Analytical Methods}

The concentration of MB 9 was measured using an ultraviolet-visible (UV-vis) spectrometer (Tianmei Techcomp Ltd., Shanghai, China) at a maximum wavelength of $522 \mathrm{~nm}$ (pure dye) and $469 \mathrm{~nm}$ $\left(\mathrm{Fe}^{2+} / \mathrm{PS}\right.$ system). The degradation percentage (\%) was calculated using Equation (4):

$$
\text { Degradation }(\%)=\frac{A_{0}-A_{t}}{A_{0}} \times 100
$$

where $A_{0}$ is the initial concentration of $M B 9$ and $A_{t}$ is the concentration of MB 9 at time $t$, respectively. The mineralization performance of the samples was investigated through the total organic carbon (TOC) with a Shimadzu TOC-5050 analyzer (Shimadzu, Japan). PS decomposition studies were conducted as described in the literature [32].

\section{Results and Discussion}

\subsection{Comparative Studies on MB 9 Degradation Efficiency}

The comparative results on MB 9 degradation efficiency by $\mathrm{HP}, \mathrm{PS}, \mathrm{Fe}^{2+}, \mathrm{Fe}^{2+} / \mathrm{HP}$ oxidation system, and $\mathrm{Fe}^{2+} / \mathrm{PS}$ oxidation system were evaluated (Figure 1a). MB 9 was hardly removed by solely using $\mathrm{Fe}^{2+}$. The degradation efficiency of the HP oxidant alone was also not satisfactory; however, the removal efficiency slightly increased when PS oxidant was solely used over a period of $30 \mathrm{~min}$. This improvement is related to the higher solubility, oxidation potential, and stability of PS at room temperature $\left(25^{\circ} \mathrm{C}\right)$ than those of $\mathrm{HP}$ [33]. The MB 9 degradation efficiency of the $\mathrm{Fe}^{2+} / \mathrm{HP}$ system was considerably higher than the sum of the efficiencies of $\mathrm{Fe}^{2+}$ alone and $\mathrm{HP}$ alone. However, the degradation percentage increased significantly when $\mathrm{Fe}^{2+}$ and PS were used together. Complete removal of $\mathrm{MB} 9$ was achieved after $30 \mathrm{~min}$. These results suggest that $\mathrm{SO}_{4}^{\bullet-}$ and $\bullet \mathrm{OH}$ radicals were generated, causing MB 9 degradation in this system [34]. Figure 1a also shows the two steps involved in MB 9 degradation: (i) fast-stage degradation, which occurred within the initial 15 min because of the rapid production of $\mathrm{SO}_{4}^{\bullet-}$ via $\mathrm{S}_{2} \mathrm{O}_{8}{ }^{2-}$ dissociation [30] and (ii) slow-stage degradation, which was related to the low concentration of the radicals. This result was also supported by the decomposition of PS dosage during degradation (Figure 1b). The consumption rate of PS was more than $40 \%$ within the first 15 min, suggesting that $\mathrm{Fe}^{2+}$ could effectively activate PS for the rapid production of $\mathrm{SO}_{4}^{\bullet-}$ radicals.
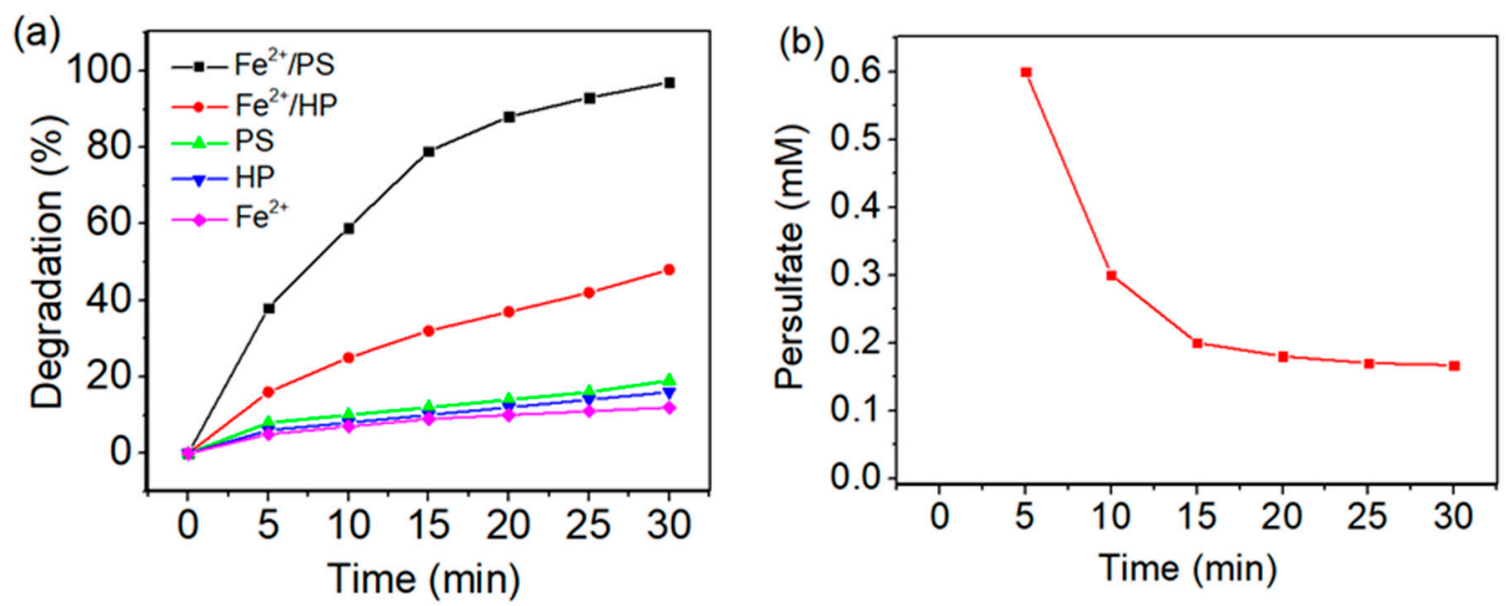

Figure 1. (a) MB 9 degradation under different conditions over time and (b) persulfate (PS) decomposition over time. Reaction conditions: $\mathrm{pH}=4.88, \mathrm{C}(\mathrm{PS})=0.8 \mathrm{mM}, \mathrm{C}\left(\mathrm{Fe}^{2+}\right)=0.7 \mathrm{mM}$, $\mathrm{C}(\mathrm{MB} 9)=0.05 \mathrm{mM}$ at $25^{\circ} \mathrm{C}$. 


\subsection{Effect of Operational Parameters}

\subsubsection{Effect of Initial $\mathrm{pH}$}

In Fenton oxidation, the initial solution $\mathrm{pH}$ is commonly regarded as one of the most significant parameters influencing the degradation efficiency of pollutants [35]. Therefore, the effect of variations in initial solution $\mathrm{pH}$ on $\mathrm{MB} 9$ degradation by the $\mathrm{Fe}^{2+} / \mathrm{PS}$ system was measured. In Figure 2, the degradation efficiency of MB 9 is strongly influenced by the initial $\mathrm{pH}$ of the solution, which shows that the percentage of degradation decreases from $82 \%$ to $32 \%$ with increasing $\mathrm{pH}$ from 2.65 to 9.24 within $30 \mathrm{~min}$. The maximum degradation percentage of MB $9(94 \%)$ was achieved at $\mathrm{pH} 4.88$ and was considered as the optimal solution $\mathrm{pH}$ for the subsequent experiments. Acidic conditions were largely favorable for $\mathrm{MB} 9$ degradation in the $\mathrm{Fe}^{2+} / \mathrm{PS}$ system. At a lower $\mathrm{pH}$ level, $\mathrm{SO}_{4}^{\bullet-}$ achieved a higher redox potential and even oxidized water to generate $\mathrm{HO} \bullet$ radicals [23]. Hydrolysis of $\mathrm{S}_{2} \mathrm{O}_{8}{ }^{2-}$ could also produce hydrogen peroxide, increasing the efficiency of MB 9 degradation in the presence of a $\mathrm{Fe}(\mathrm{II})$-activated process [36]. Meanwhile, higher $\mathrm{pH}$ levels are suitable for generating $\mathrm{Fe}^{2+}$ hydroxyl complexes and $\mathrm{Fe}^{3+}$ oxyhydroxides, both of which are considered as weak activators for PS [37]. Thus, the efficiency of MB 9 degradation decreased as $\mathrm{pH}$ increased. Previous studies on carbamazepine degradation by a Fe(II)-activated PS process also demonstrated that alkaline $\mathrm{pH}$ leads to reduced degradation efficiency [26].

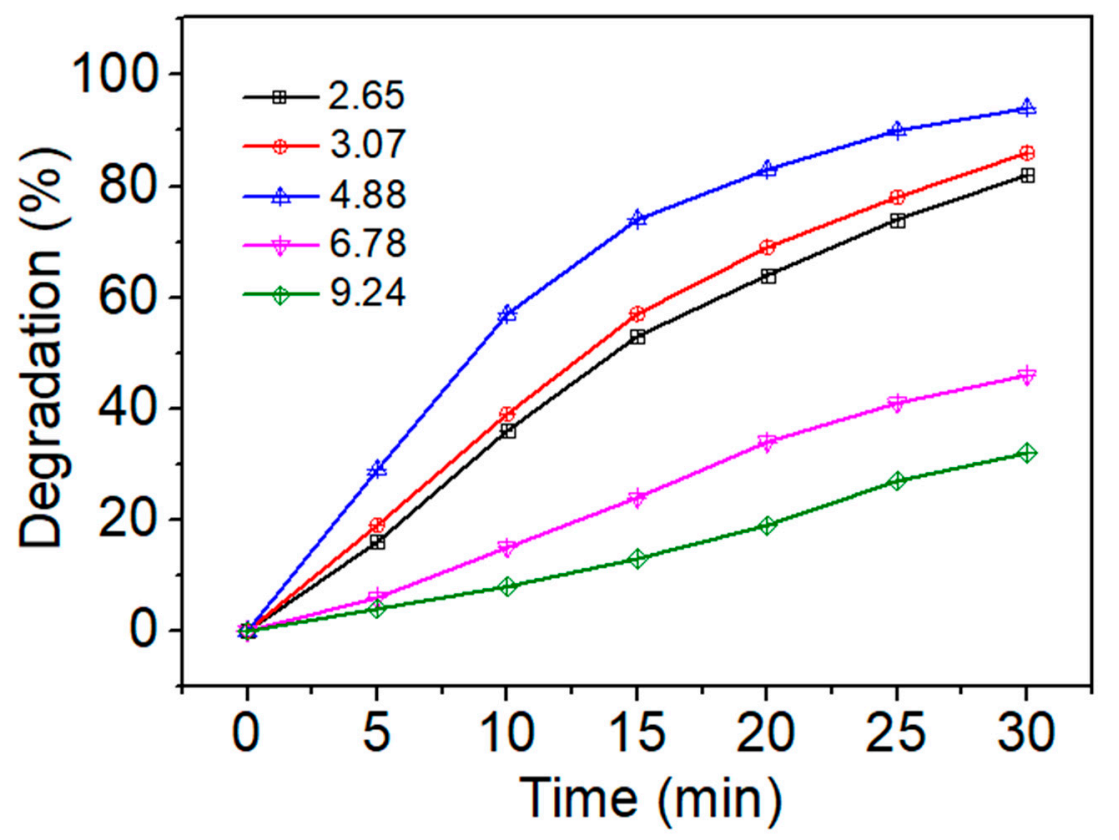

Figure 2. Effect of initial $\mathrm{pH}$ on $\mathrm{MB} 9$ degradation. Reaction conditions: $\mathrm{C}(\mathrm{PS})=0.8 \mathrm{mM}, \mathrm{C}\left(\mathrm{Fe}^{2+}\right)=0.7 \mathrm{mM}$, $\mathrm{C}(\mathrm{MB} 9)=0.05 \mathrm{mM}$ at $25^{\circ} \mathrm{C}$.

\subsubsection{Effect of PS Concentration}

The effect of oxidants has often been considered a parameter affecting pollutant removal because oxidants are the source of radical production in typical Fenton oxidation [34]. Thus, the influence of variations in PS concentrations on MB 9 degradation efficiency was evaluated. The results in Figure 3 show that the maximum efficiency of MB 9 degradation is achieved when PS concentration is set to $0.8 \mathrm{mM}$; at either higher or lower PS concentration, the degradation efficiency declines. By increasing the concentration from 0.2 to $0.8 \mathrm{mM}$, the efficiency of MB 9 degradation linearly improved from $50 \%$ to $95 \%$ after a 30 min reaction. Thus, the optimal PS concentration was determined to be $0.8 \mathrm{mM}$ for the subsequent experiments. At higher PS concentrations, more PS molecules could react with $\mathrm{Fe}^{2+}$, and a greater amount of reactive radicals $\left(\mathrm{SO}_{4}^{\bullet-}\right)$ was produced for $\mathrm{MB} 9$ degradation, 
improving the degradation efficiency during the reaction [38]. Meanwhile, the efficiency of MB 9 degradation decreased to $87 \%$ with a further increase in PS concentration to $1.0 \mathrm{mM}$. This result is attributed to the excess PS in the solution, which may act as the scavengers of radicals, inhibiting the efficiency of MB 9 degradation during the reaction. This finding is consistent with a previous report on sulfamonomethoxine degradation by an iron-activated PS process [39].

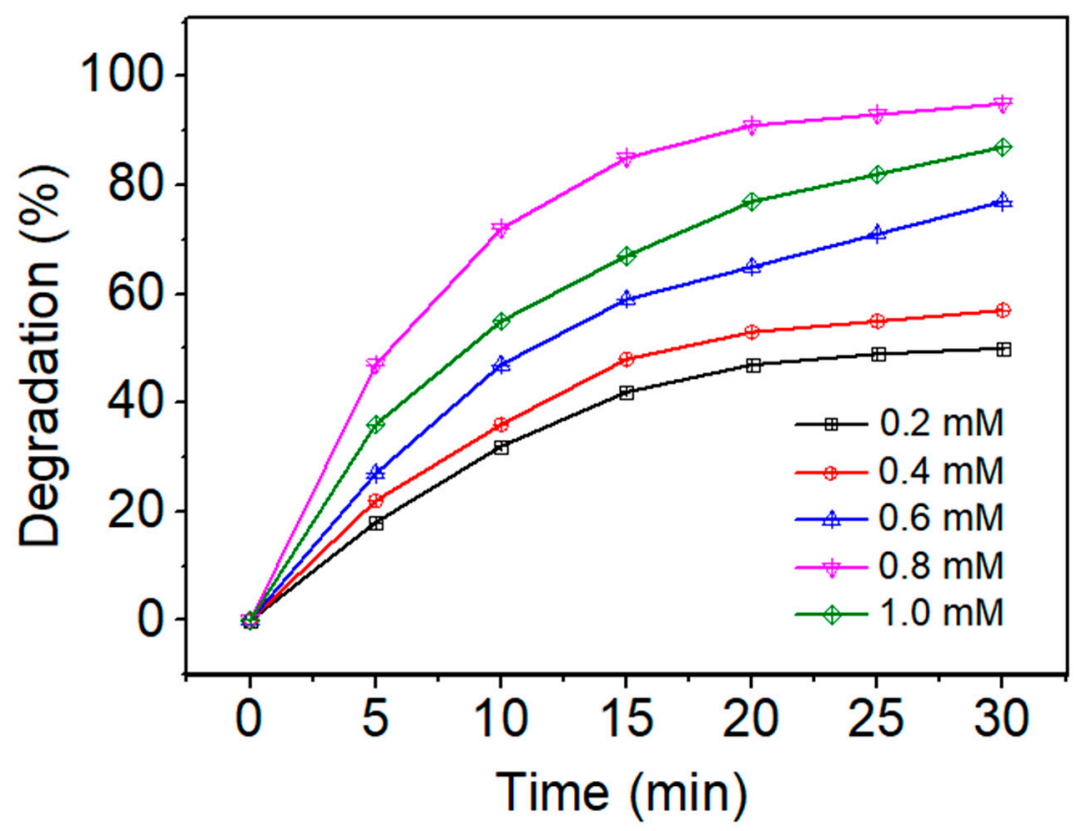

Figure 3. Effect of PS concentration on MB 9 degradation. Reaction conditions: $\mathrm{pH}=4.88$, $\mathrm{C}\left(\mathrm{Fe}^{2+}\right)=0.7 \mathrm{mM}, \mathrm{C}(\mathrm{MB} 9)=0.05 \mathrm{mM}$ at $25^{\circ} \mathrm{C}$.

\subsubsection{Effect of $\mathrm{Fe}^{2+}$ Concentration}

The concentration of $\mathrm{Fe}^{2+}$ markedly affected the efficiency of MB 9 degradation. Figure 4 presents the MB 9 degradation studies under different $\mathrm{Fe}^{2+}$ concentrations. An increase in $\mathrm{Fe}^{2+}$ concentration from 0.1 to $0.7 \mathrm{mM}$ caused a significant enhancement in the efficiency of MB 9 degradation from $73 \%$ to $93 \%$ (Figure 4). The higher concentration of $\mathrm{Fe}^{2+}$ ions that corresponds to a substantial amount of $\mathrm{Fe}^{2+}$ can activate PS molecules to generate $\mathrm{SO}_{4}^{--}$radicals in the solution, mainly improving the efficiency of $\mathrm{MB} 9$ degradation in the $\mathrm{Fe}^{2+} / \mathrm{PS}$ system. Thus, $0.7 \mathrm{mM}$ is determined as the optimal concentration of $\mathrm{Fe}^{2+}$. However, a further increase in $\mathrm{Fe}^{2+}$ concentration from 0.7 to $1.5 \mathrm{mM}$ markedly reduced the efficiency of MB 9 degradation from $93 \%$ to $38 \%$. This occurrence can be interpreted in two ways: first, the excessive amount of $\mathrm{Fe}^{2+}$ accelerated the scavenging activities of $\mathrm{SO}_{4}^{\bullet-}$ radicals in the solution [40], and second, a higher concentration of $\mathrm{Fe}^{2+}$ shifts the equilibrium toward the Fe-complex formation with the MB 9 pollutant in the solution [41]. Similar findings have also been reported in the literature on the degradation of different types of pollutants in the $\mathrm{Fe}^{2+} / \mathrm{PS}$ system [28,42].

\subsubsection{Effect of MB 9 Concentrations}

The initial concentration of pollutants has been reported to considerably influence degradation efficiency $[43,44]$. In the present study, the influence of the initial MB 9 concentration of the $\mathrm{Fe}^{2+} / \mathrm{PS}$ system was evaluated, and the results are shown in Figure 5. Under these experimental conditions, reduced MB 9 concentration indicated enhanced degradation efficiency. Accordingly, the degradation efficiency was markedly reduced from $94 \%$ to $51 \%$ as the initial concentration of MB 9 increased from 0.05 to $1.5 \mathrm{mM}$. The reason is that a higher concentration of MB 9 may reduce the production of reactive radicals by the dissociation of PS molecules. In addition, more MB 9 molecules consume more radicals, resulting in an insufficient amount of radicals to degrade the excess MB 9, and a lower 
degradation efficiency [45-47]. By contrast, a lower dye concentration is suitable for efficient MB 9 degradation, due to many $\mathrm{SO}_{4}^{--}$radicals produced, ensuring a higher degradation percentage at a low MB 9 concentration.

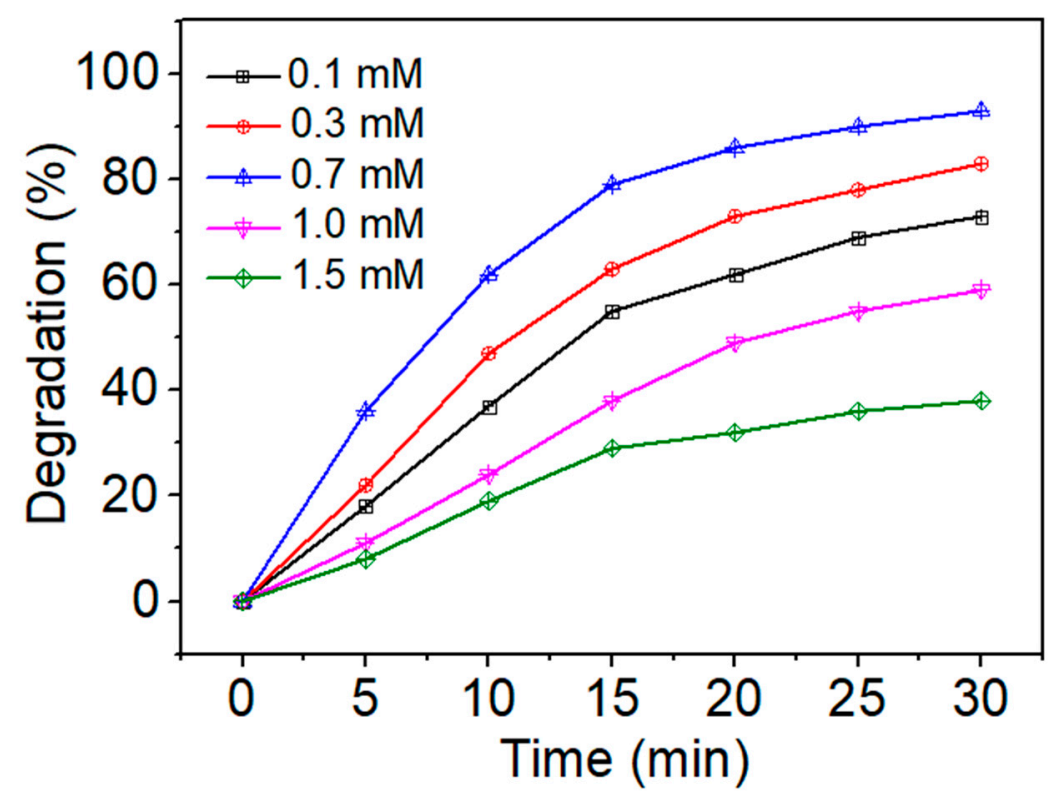

Figure 4. Effect of $\mathrm{Fe}^{2+}$ concentration on $\mathrm{MB} 9$ degradation. Reaction conditions: $\mathrm{pH}=4.88$, $\mathrm{C}(\mathrm{PS})=0.8 \mathrm{mM}, \mathrm{C}(\mathrm{MB} 9)=0.05 \mathrm{mM}$ at $25^{\circ} \mathrm{C}$.

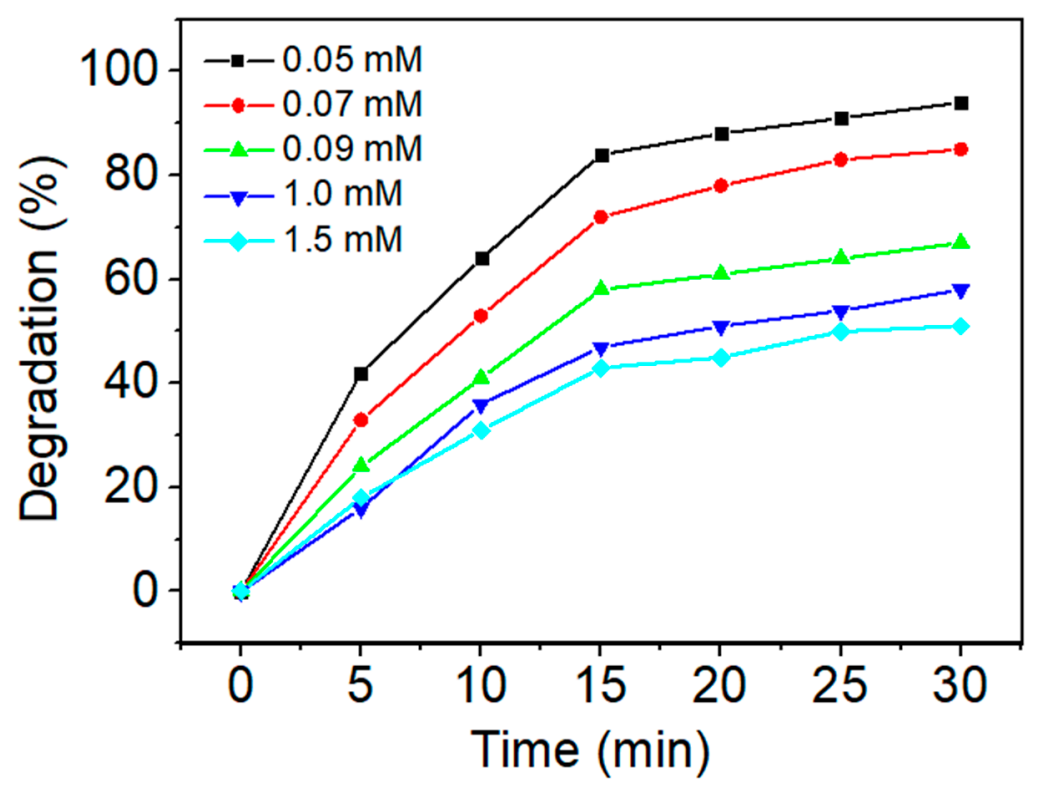

Figure 5. Effect of the initial dye concentration on MB 9 degradation. Reaction conditions: $\mathrm{pH}=4.88$, $\mathrm{C}(\mathrm{PS})=0.8 \mathrm{mM}, \mathrm{C}\left(\mathrm{Fe}^{2+}\right)=0.7 \mathrm{mM}$ at $25^{\circ} \mathrm{C}$.

\subsubsection{Effect of Inorganic Anions}

Various types of inorganic salt often exist in effluents from textile and dyeing industries, which may influence the efficiency of dye degradation in Fenton oxidation $[48,49]$. Thus, the effects of $\mathrm{Cl}^{-}$ and $\mathrm{HCO}_{3}{ }^{-}$anions on the efficiency of $\mathrm{MB} 9$ degradation in the $\mathrm{Fe}^{2+} / \mathrm{PS}$ system were investigated, and the results are presented in Figure 6a. It was noticed that without the addition of inorganic ions in the solution the degradation efficiency of MB 9 was higher, whereas the addition of $\mathrm{Cl}^{-}$in the solution decreased the degradation efficiency of MB 9, possibly due to the formation of less reactive chlorine 
species such as $\mathrm{Cl}^{\bullet}, \mathrm{Cl}^{\bullet-}$ and $\mathrm{Cl}_{2}$, as shown in Equations (5)-(7) [50,51]. This result was similar to the previously reported by Fang et al. [52] demonstrated that the efficiency of polychlorinated biphenyl degradation in a PS-activated system was markedly inhibited by the addition of $\mathrm{Cl}^{-}$. On the other hand, Wang et al. [53] reported that $\mathrm{Cl}^{-}$positively affected the efficiency of rhodamine $\mathrm{B}$ degradation in the $\mathrm{Fe}^{2+} / \mathrm{PS}$ system. However, this difference in the performance of $\mathrm{Cl}^{-}$in the PS-activated system was attributed to the variations in the molecular structure of pollutants [54].

$$
\begin{gathered}
\mathrm{SO}_{4}^{\bullet-}+\mathrm{Cl}^{-} \leftrightarrow \mathrm{SO}_{4}^{2-}+\mathrm{Cl}^{\bullet} \\
\mathrm{Cl}^{\bullet}+\mathrm{Cl}^{-} \leftrightarrow \mathrm{Cl}_{2}^{\bullet-} \\
\mathrm{Cl}_{2}^{\bullet^{-}}+\mathrm{Cl}_{2}^{\bullet^{-}} \rightarrow 2 \mathrm{Cl}^{-}+\mathrm{Cl}_{2}
\end{gathered}
$$
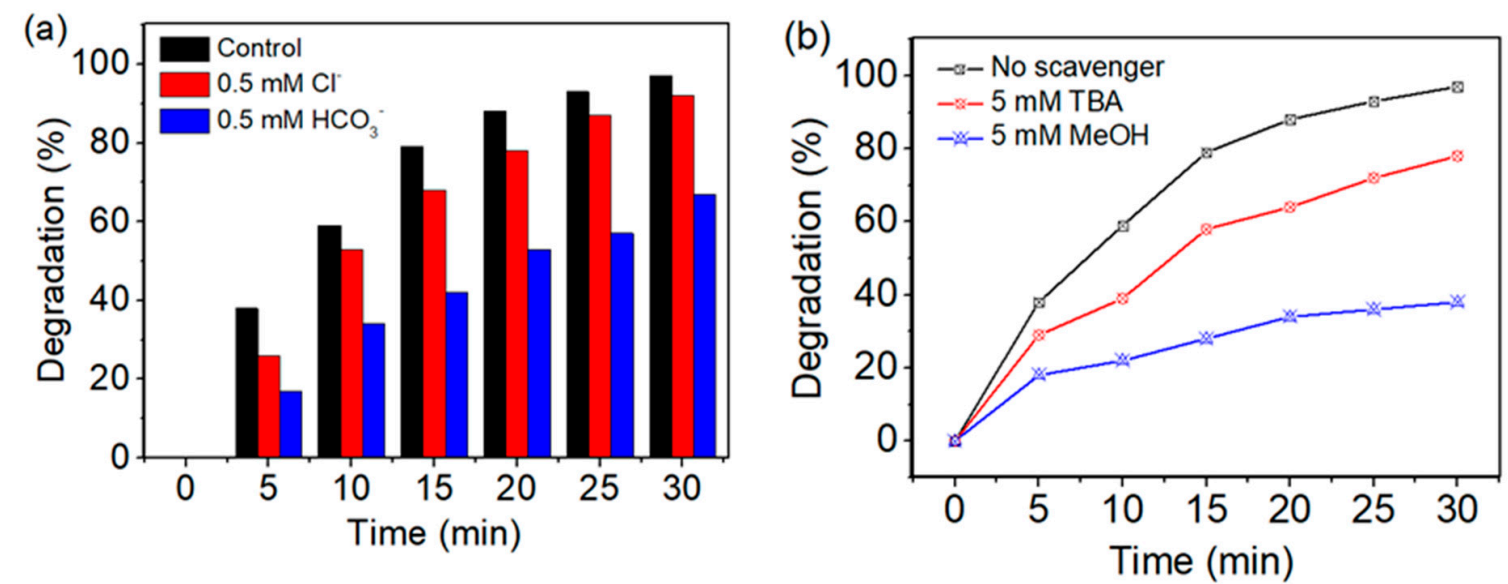

Figure 6. (a) Effect of inorganic anions on MB 9 degradation; (b) Effect of scavengers on MB 9 degradation. Reaction conditions: $\left.\mathrm{pH}=4.88, \mathrm{C}(\mathrm{PS})=0.8 \mathrm{mM}, \mathrm{C}(\mathrm{Fe})^{+}\right]=0.7 \mathrm{mM}, \mathrm{C}(\mathrm{MB} 9)=0.05 \mathrm{mM}$ at $25{ }^{\circ} \mathrm{C}$.

$\mathrm{HCO}_{3}{ }^{-}$is a vital compound in water. Here, we investigated the influence of $\mathrm{HCO}_{3}{ }^{-}$on $\mathrm{MB} 9$ degradation performance. As shown, the degradation efficiency of MB 9 markedly decreased to $67 \%$ by the addition of $\mathrm{HCO}_{3}{ }^{-}$in the solution (Figure 6a). This inhibition arises from the rapid consumption of both $\mathrm{SO}_{4}^{\bullet-}$ and $\bullet \mathrm{OH}$ radicals owing to the scavenging role of bicarbonate in the solution [55]. A previous report by Weng et al. [56] described that the presence of bicarbonate induced Fe-complex formation in the solution, affecting the availability of $\mathrm{Fe}^{2+}$ for the production of $\mathrm{SO}_{4}^{--}$radicals to oxidize compounds in the $\mathrm{Fe}^{2+} / \mathrm{PS}$ system, hence, the degradation efficiency of MB 9 was reduced.

\subsubsection{Effect of Scavengers}

Pollutant degradation in the $\mathrm{Fe}^{2+} / \mathrm{PS}$ system is caused by oxidative free radicals such as $\mathrm{SO}_{4}^{\bullet-}$ and - $\mathrm{OH}[39,57]$. Therefore, in the current study, radical quenching experiments were conducted in the presence of tertiary butyl alcohol (TBA) and methanol (MeOH) to determine the potentially dominant radicals for $\mathrm{MB} 9$ degradation. $\mathrm{MeOH}$ is a strong scavenger of $\bullet \mathrm{OH}$ and weak scavenger of $\mathrm{SO}_{4}^{\bullet-}$ because the rate constant of the $\mathrm{MeOH}+\mathrm{SO}_{4}^{\circ-}$ reaction is $1 \times 10^{7} \mathrm{M}^{-1} \mathrm{~s}^{-1}$, while that of the $\mathrm{MeOH}+$ $\bullet \mathrm{OH}$ reaction is $8 \times 10^{8} \mathrm{M}^{-1} \mathrm{~s}^{-1}$, whereas TBA can only scavenge of ${ }^{\bullet} \mathrm{OH}$ radicals [58]. The efficiency of MB 9 degradation decreased to $78 \%$ by the addition of TBA (Figure $6 \mathrm{~b}$ ). This degradation efficiency was less than that without a scavenger, but no significant difference was found. However, the efficiency of MB 9 degradation was significantly reduced to $38 \%$ with the addition of $\mathrm{MeOH}$. This result indicated the presence of both $\mathrm{SO}_{4}^{\bullet-}$ and ${ }^{\bullet} \mathrm{OH}$ radicals are responsible for $\mathrm{MB} 9$ degradation in the $\mathrm{Fe}^{2+} / \mathrm{PS}$ system. This finding was consistent with previous studies in the PS activation oxidation system $[59,60]$. 


\subsection{Degradation Pathway of $M B 9$}

Structural changes in MB 9 during the conventional Fenton $\left(\mathrm{Fe}^{2}+/ \mathrm{HP}\right)$ and Fenton-activated persulfate $\left(\mathrm{Fe}^{2+} / \mathrm{PS}\right)$ degradation studies were investigated by UV-vis spectroscopy; the results are shown in Figure $7 \mathrm{a}, \mathrm{b}$, respectively. In the conventional Fenton $\left(\mathrm{Fe}^{2+} / \mathrm{HP}\right)$ process, the absorption spectra of the pure dye have two characteristic peaks at wavelengths of 311 and $522 \mathrm{~nm}$ (Figure 7a). The maximum absorption peak in the visible region at $522 \mathrm{~nm}$ was responsible for the chromophore bond, and the shoulder peak at $311 \mathrm{~nm}$ in the UV region was attributed to the aromatic rings. During degradation, the peak maximum was shifted to $469 \mathrm{~nm}$ when the Fe-complex was formed in their structure. This complex also added a broad protuberance from 650 to $750 \mathrm{~nm}$, which could be due to the increase in ligand conformational rigidity with $\mathrm{Fe}^{3+}$ cations after the coordination bond in their terminal hydroxyl group $[17,61]$. However, no new characteristic peak appeared in the presence of the $\mathrm{Fe}^{2+} / \mathrm{PS}$ system, suggesting that the chromophore-that is, the cleavage of the azo bond of the MB 9 structure-was completely destroyed during degradation studies (Figure $7 \mathrm{~b}$ ). As a result, the degradation efficiency was higher than the conventional Fenton process. Table 1 also shows that $\mathrm{Fe}^{2+} / \mathrm{PS}$ is one of the most effective systems for MB 9 degradation.
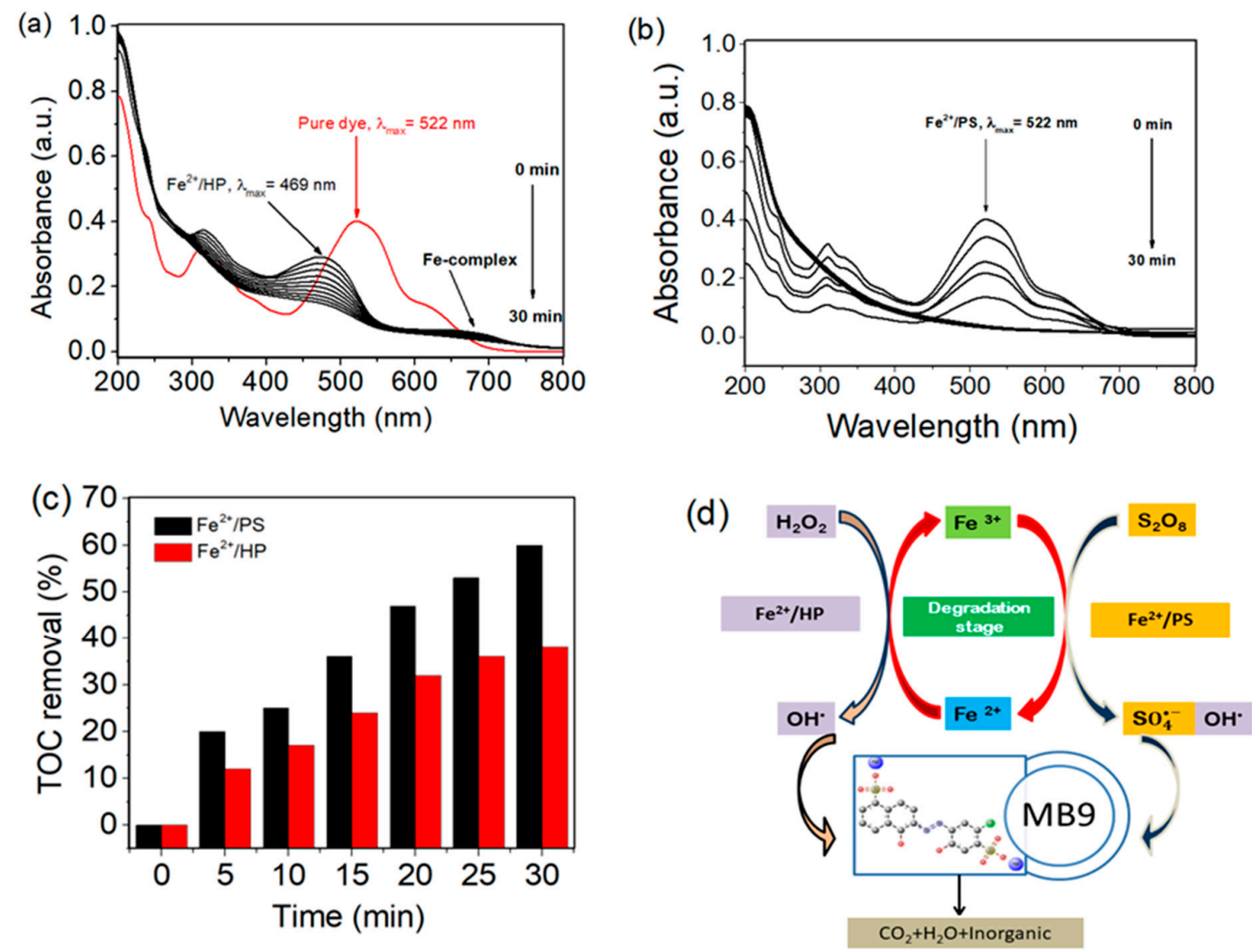

Figure 7. UV-vis spectra of MB 9 degradation in the $\mathrm{Fe}^{2+} / \mathrm{HP}(\mathbf{a})$ and $\mathrm{Fe}^{2+} / \mathrm{PS}$ system (b); (c) TOC removal. Reaction conditions $\mathrm{pH}=4.88, \mathrm{C}(\mathrm{PS}) /(\mathrm{HP})=0.8 \mathrm{mM}, \mathrm{C}\left(\mathrm{Fe}^{2+}\right)=0.7 \mathrm{mM}, \mathrm{C}(\mathrm{MB} 9)=0.05 \mathrm{mM}$ at $25^{\circ} \mathrm{C} ;(\mathbf{d})$ proposed mechanism of MB9 degradation in both systems. 
Table 1. Comparison of MB 9 removal using the proposed method and by other methods.

\begin{tabular}{ccccc}
\hline Samples & Methods & Conc. of MB 9 & $\begin{array}{c}\text { Removal } \\
\text { Efficiency (\%) }\end{array}$ & Ref \\
\hline Fungal peroxidase enzymes & batch shake flasks & $10 \mathrm{mg} \mathrm{L}^{-1}$ & 97 & {$[62,63]$} \\
\hline Fungal peroxidase enzymes & $\begin{array}{c}\text { rotating biological } \\
\text { contactor (RBC) reactor }\end{array}$ & $10 \mathrm{mg} \mathrm{L}^{-1}$ & 98 & {$[64]$} \\
\hline Fungal peroxidase enzymes & media constituents & $10 \mathrm{mg} \mathrm{L}^{-1}$ & 100 & {$[65]$} \\
\hline Ionic liquid & adsorption & $100 \mu \mathrm{mol}$ & 98.28 & {$[66]$} \\
\hline $\mathrm{Fe}_{2}\left(\mathrm{SO}_{4}\right)_{3}$ & coagulation & $100 \mu \mathrm{mol}$ & 28 & {$[66]$} \\
\hline Fenton & oxidation & $100 \mu \mathrm{mol}$ & 98 & {$[66]$} \\
\hline $\mathrm{CeO}_{2}$ & adsorption & $200 \mathrm{mg} \mathrm{L}$ & 91 & {$[67]$} \\
\hline Fenton & oxidation & $0.05 \mathrm{mM}$ & 48 & This work \\
\hline Fenton-activated persulfate & oxidation & $0.05 \mathrm{mM}$ & 97 & This work \\
\hline
\end{tabular}

With the $\mathrm{Fe}^{2+} / \mathrm{PS}$ system, the degree of mineralization (TOC) removal percentage gradually increased to $60 \%$, whereas with the $\mathrm{Fe}^{2+} / \mathrm{HP}$ system, TOC removal was only $38 \%$ (Figure $7 \mathrm{c}$ ). This result demonstrates that MB 9 molecules were efficiently mineralized into $\mathrm{H}_{2} \mathrm{O}$ and $\mathrm{CO}_{2}$ using the $\mathrm{Fe}^{2+} / \mathrm{PS}$ system (Figure 7d). Therefore, the degradation and mineralization of MB 9 can be effectively obtained using the PS activation system without any complex formation during degradation.

\section{Conclusions}

The present study shows that Fenton-activated PS is a highly efficient system for MB 9 degradation, with a degradation percentage exceeding $95 \%$ in an aqueous solution. In the $\mathrm{Fe}^{2+} / \mathrm{PS}$ system, the optimal operating conditions were as follows: initial solution $\mathrm{pH}=4.88$, concentration of PS (PS) $=0.8 \mathrm{mM}$, concentration of iron (II) $\left(\mathrm{Fe}^{2+}\right)=0.7 \mathrm{mM}$, and concentration of initial dye solution (MB 9) $=0.05 \mathrm{mM}$ at $25{ }^{\circ} \mathrm{C}$. The presence of certain anions, such as $\mathrm{HCO}_{3}{ }^{-}$, negatively affected $\mathrm{MB} 9$ degradation, whereas the addition of $\mathrm{Cl}^{-}$anions improved the efficiency of degradation. Methanol as a scavenger strongly inhibited the efficiency of $\mathrm{MB} 9$ degradation, confirming that $\mathrm{SO}_{4}^{\bullet-}$ and ${ }^{\bullet} \mathrm{OH}$ radicals are actively responsible for MB 9 degradation. The conventional Fenton process was not efficient for MB 9 degradation because of their Fe complex formation behavior during the reaction. Finally, Fenton-activated PS can be used as an effective oxidation system for the degradation of recalcitrant compounds from wastewater.

Author Contributions: Conceptualization, F.Y.T. and M.N.P.; formal analysis, F.Y.T., Y.C. and M.N.P.; methodology, M.N.P.; software, F.Y.T.; data curation, M.N.P.; writing-original draft preparation, M.N.P.; writing-review and editing, V.N., T.Z., F.Y.T., D.X. and Y.C.; supervision, V.N., Y.C. and F.Y.T.; funding acquisition, Y.C. and V.N.

Funding: This research work was funded by the Science and Technology Project of Educational Commission of Hubei Province (No. Q20181706).

Acknowledgments: Authors are grateful to Color Root and Runhe Chemicals Ltd., China, for providing the full M.Sc. scholarship (No. 2014 RHS017) at Wuhan Textile University, China. The PhD School in Risk and Sustainability in Civil Engineering, Environmental and Construction and the Sanitary and Environmental Engineering Division (SEED) Laboratory of the University of Salerno, Italy, are also acknowledged for the PhD scholarship (XXXIV CYCLE) of Nahid Pervez. This research activity is linked to the FARB projects funded by the University of Salerno and coordinated by Vincenzo Naddeo.

Conflicts of Interest: The authors declare no conflict of interest. 


\section{References}

1. Wu, L.; Xie, Q.; Lv, Y.; Wu, Z.; Liang, X.; Lu, M.; Nie, Y. Degradation of Methylene Blue via Dielectric Barrier Discharge Plasma Treatment. Water 2019, 11, 1818. [CrossRef]

2. Angelakis, A.; Snyder, S. Wastewater treatment and reuse: Past, present, and future. Water 2015, 7, 4887-4895. [CrossRef]

3. Telegin, F.Y.; Ran, J.H.; Morshed, M.; Pervez, M.N.; Sun, L.; Zhang, C.; Priazhinikova, V.G. Structure and Properties of Dyes in Coloration of Textiles: Application of Fragment Approach. Key Engineering Materials; Trans Tech Publications: Stafa-Zurich, Switzerland, 2016; pp. 261-266.

4. El-Wakiel, N.A.; Rizk, H.F.; Ibrahim, S.A. Synthesis and characterization of metal complexes of azo dye based on 5-nitro-8-hydroxyquinoline and their applications in dyeing polyester fabrics. Appl. Organomet. Chem. 2017, 31, e3723. [CrossRef]

5. Cai, Y.; David, S.; Pailthorpe, M. Dyeing of jute and jute/cotton blend fabrics with 2:1 pre-metallised dyes. Dye. Pigment. 2000, 45, 161-168. [CrossRef]

6. Ding, Y.; Freeman, H.S. Mordant dye application on cotton: Optimisation and combination with natural dyes. Coloration Technol. 2017, 133, 369-375. [CrossRef]

7. Edwards, L.C.; Freeman, H.S. Synthetic dyes based on environmental considerations. Part 3: Aquatic toxicity of iron-complexed azo dyes. Coloration Technol. 2005, 121, 265-270. [CrossRef]

8. Hong, E.; Yeneneh, A.M.; Sen, T.K.; Ang, H.M.; Kayaalp, A. A comprehensive review on rheological studies of sludge from various sections of municipal wastewater treatment plants for enhancement of process performance. Adv. Colloid Interface Sci. 2018, 257, 19-30. [CrossRef]

9. Pervez, M.N.; Stylios, G.K. Investigating the synthesis and characterization of a novel "green" H2O2-assisted, water-soluble chitosan/polyvinyl alcohol nanofiber for environmental end uses. Nanomaterials 2018, 8, 395. [CrossRef]

10. Clavijo, C.; Osma, J.F. Functionalized leather: A novel and effective hazardous solid waste adsorbent for the removal of the diazo dye congo red from aqueous solution. Water 2019, 11, 1906. [CrossRef]

11. Gomez-Herrero, E.; Tobajas, M.; Polo, A.; Rodriguez, J.J.; Mohedano, A.F. Removal of imidazolium-based ionic liquid by coupling Fenton and biological oxidation. J. Hazard. Mater. 2019, 365, 289-296. [CrossRef]

12. Vilardi, G.; Sebastiani, D.; Miliziano, S.; Verdone, N.; Di Palma, L. Heterogeneous nZVI-induced Fenton oxidation process to enhance biodegradability of excavation by-products. Chem. Eng. J. 2018, 335, 309-320. [CrossRef]

13. Munoz, M.; De Pedro, Z.M.; Casas, J.A.; Rodriguez, J.J. Preparation of magnetite-based catalysts and their application in heterogeneous Fenton oxidation-a review. Appl. Catal. B Environ. 2015, 176, 249-265. [CrossRef]

14. Olmez-Hanci, T.; Arslan-Alaton, I. Comparison of sulfate and hydroxyl radical based advanced oxidation of phenol. Chem. Eng. J. 2013, 224, 10-16. [CrossRef]

15. Shushina, I.; Ran, J.H.; Telegin, F.Y. Destruction of azo dyes in chemical, biochemical and photochemical processes. In Proceedings of the Book of papers, Regional Conference "Innovations of Youth Science"; SP University of Technology and Design: St Petersburg, Russia, 23-27 April 2012.

16. Shushina, I.; Ran, J.H.; Telegin, F.Y. The role of complex formation in inhibition of catalytic oxidative destruction of mordant dyes. In Proceedings of the Book of Papers, Regional Conference "Progress 2012"; Ivanovo State Academy of Textiles: Ivanovo, Russia, 30 May 2012.

17. Ran, J.H.; Shushina, I.; Priazhnikova, V.; Telegin, F. Inhibition of Mordant Dyes Destruction in Fenton Reaction. Adv. Mater. Res. 2013, 821, 493-496. [CrossRef]

18. Arellano, M.; Pazos, M.; Sanromán, M.Á. Sulfate Radicals-Based Technology as a Promising Strategy for Wastewater. Water 2019, 11, 1695. [CrossRef]

19. Guerra-Rodríguez, S.; Rodríguez, E.; Singh, D.N.; Rodríguez-Chueca, J. Assessment of sulfate radical-based advanced oxidation processes for water and wastewater treatment: A Review. Water 2018, 10, 1828. [CrossRef]

20. Wacławek, S.; Lutze, H.V.; Grübel, K.; Padil, V.V.; Černík, M.; Dionysiou, D.D. Chemistry of persulfates in water and wastewater treatment: A review. Chem. Eng. J. 2017, 330, 44-62. [CrossRef] 
21. Wu, B.; Gu, G.; Deng, S.; Liu, D.; Xiong, X. Efficient natural pyrrhotite activating persulfate for the degradation of O-isopropyl-N-ethyl thionocarbamate: Iron recycle mechanism and degradation pathway. Chemosphere 2019, 224, 120-127. [CrossRef]

22. Ahn, Y.-Y.; Bae, H.; Kim, H.-I.; Kim, S.-H.; Kim, J.-H.; Lee, S.-G.; Lee, J. Surface-loaded metal nanoparticles for peroxymonosulfate activation: Efficiency and mechanism reconnaissance. Appl. Catal. B Environ. 2019, 241, 561-569. [CrossRef]

23. Liang, C.; Su, H.-W. Identification of sulfate and hydroxyl radicals in thermally activated persulfate. Ind. Eng. Chem. Res. 2009, 48, 5558-5562. [CrossRef]

24. Liu, X.; Yuan, B.; Zou, J.; Wu, L.; Dai, L.; Ma, H.; Li, K.; Ma, J. Cu (II)-enhanced degradation of acid orange 7 by $\mathrm{Fe}$ (II)-activated persulfate with hydroxylamine over a wide $\mathrm{pH}$ range. Chemosphere 2020, 238, 124533. [CrossRef] [PubMed]

25. Rastogi, A.; Al-Abed, S.R.; Dionysiou, D.D. Sulfate radical-based ferrous-peroxymonosulfate oxidative system for PCBs degradation in aqueous and sediment systems. Appl. Catal. B Environ. 2009, 85, 171-179. [CrossRef]

26. Rao, Y.; Qu, L.; Yang, H.; Chu, W. Degradation of carbamazepine by Fe (II)-activated persulfate process. J. Hazard. Mater. 2014, 268, 23-32. [CrossRef] [PubMed]

27. Wang, S.; Wu, J.; Lu, X.; Xu, W.; Gong, Q.; Ding, J.; Dan, B.; Xie, P. Removal of acetaminophen in the Fe2+/persulfate system: Kinetic model and degradation pathways. Chem. Eng. J. 2019, 358, 1091-1100. [CrossRef]

28. Shang, W.; Dong, Z.; Li, M.; Song, X.; Zhang, M.; Jiang, C.; Feiyun, S. Degradation of diatrizoate in water by Fe (II)-activated persulfate oxidation. Chem. Eng. J. 2019, 361, 1333-1344. [CrossRef]

29. Zhu, J.-P.; Lin, Y.-L.; Zhang, T.-Y.; Cao, T.-C.; Xu, B.; Pan, Y.; Zhang, X.-T.; Gao, N.-Y. Modelling of iohexol degradation in a Fe (II)-activated persulfate system. Chem. Eng. J. 2019, 367, 86-93. [CrossRef]

30. Kusic, H.; Peternel, I.; Ukic, S.; Koprivanac, N.; Bolanca, T.; Papic, S.; Bozic, A.L. Modeling of iron activated persulfate oxidation treating reactive azo dye in water matrix. Chem. Eng. J. 2011, 172, 109-121. [CrossRef]

31. Rodriguez, S.; Vasquez, L.; Costa, D.; Romero, A.; Santos, A. Oxidation of Orange G by persulfate activated by Fe (II), Fe (III) and zero valent iron (ZVI). Chemosphere 2014, 101, 86-92. [CrossRef]

32. Sellers, R.M. Spectrophotometric determination of hydrogen peroxide using potassium titanium (IV) oxalate. Analyst 1980, 105, 950-954. [CrossRef]

33. Lutze, H.V.; Kerlin, N.; Schmidt, T.C. Sulfate radical-based water treatment in presence of chloride: Formation of chlorate, inter-conversion of sulfate radicals into hydroxyl radicals and influence of bicarbonate. Water Res. 2015, 72, 349-360. [CrossRef]

34. Han, D.; Wan, J.; Ma, Y.; Wang, Y.; Li, Y.; Li, D.; Guan, Z. New insights into the role of organic chelating agents in Fe (II) activated persulfate processes. Chem. Eng. J. 2015, 269, 425-433. [CrossRef]

35. Guan, R.; Yuan, X.; Wu, Z.; Wang, H.; Jiang, L.; Zhang, J.; Li, Y.; Zeng, G.; Mo, D. Accelerated tetracycline degradation by persulfate activated with heterogeneous magnetic NixFe3- xO4 catalysts. Chem. Eng. J. 2018, 350, 573-584. [CrossRef]

36. Liang, C.; Bruell, C.J.; Marley, M.C.; Sperry, K.L. Persulfate oxidation for in situ remediation of TCE. I. Activated by ferrous ion with and without a persulfate-thiosulfate redox couple. Chemosphere 2004, 55, 1213-1223. [CrossRef] [PubMed]

37. Stefánsson, A. Iron (III) hydrolysis and solubility at 25 C. Environ. Sci. Technol. 2007, 41, 6117-6123. [CrossRef] [PubMed]

38. Li, R.; Jin, X.; Megharaj, M.; Naidu, R.; Chen, Z. Heterogeneous Fenton oxidation of 2, 4-dichlorophenol using iron-based nanoparticles and persulfate system. Chem. Eng. J. 2015, 264, 587-594. [CrossRef]

39. Yan, J.; Lei, M.; Zhu, L.; Anjum, M.N.; Zou, J.; Tang, H. Degradation of sulfamonomethoxine with Fe3O4 magnetic nanoparticles as heterogeneous activator of persulfate. J. Hazard. Mater. 2011, 186, 1398-1404. [CrossRef]

40. Dehghan, S.; Kakavandi, B.; Kalantary, R.R. Heterogeneous sonocatalytic degradation of amoxicillin using $\mathrm{ZnO@} \mathrm{Fe3O4} \mathrm{magnetic} \mathrm{nanocomposite:} \mathrm{Influential} \mathrm{factors,} \mathrm{reusability} \mathrm{and} \mathrm{mechanisms.} \mathrm{J.} \mathrm{Mol.} \mathrm{Liq.} \mathrm{2018,}$ 264, 98-109. [CrossRef]

41. Kakavandi, B.; Takdastan, A.; Jaafarzadeh, N.; Azizi, M.; Mirzaei, A.; Azari, A. Application of Fe3O4@ C catalyzing heterogeneous UV-Fenton system for tetracycline removal with a focus on optimization by a response surface method. J. Photochem. Photobiol. A Chem. 2016, 314, 178-188. [CrossRef] 
42. Long, A.; Lei, Y.; Zhang, H. Degradation of toluene by a selective ferrous ion activated persulfate oxidation process. Ind. Eng. Chem. Res. 2014, 53, 1033-1039. [CrossRef]

43. Ayoub, G.; Ghauch, A. Assessment of bimetallic and trimetallic iron-based systems for persulfate activation: Application to sulfamethoxazole degradation. Chem. Eng. J. 2014, 256, 280-292. [CrossRef]

44. Wu, J.; Zhang, H.; Qiu, J. Degradation of Acid Orange 7 in aqueous solution by a novel electro/Fe2+/peroxydisulfate process. J. Hazard. Mater. 2012, 215, 138-145. [CrossRef] [PubMed]

45. Zha, S.; Cheng, Y.; Gao, Y.; Chen, Z.; Megharaj, M.; Naidu, R. Nanoscale zero-valent iron as a catalyst for heterogeneous Fenton oxidation of amoxicillin. Chem. Eng. J. 2014, 255, 141-148. [CrossRef]

46. Wang, J.; Wang, S. Activation of persulfate (PS) and peroxymonosulfate (PMS) and application for the degradation of emerging contaminants. Chem. Eng. J. 2018, 334, 1502-1517. [CrossRef]

47. Heidari, M.R.; Varma, R.S.; Ahmadian, M.; Pourkhosravani, M.; Asadzadeh, S.N.; Karimi, P.; Khatami, M. Photo-fenton like catalyst system: Activated carbon/CoFe2O4 nanocomposite for reactive dye removal from textile wastewater. Appl. Sci. 2019, 9, 963. [CrossRef]

48. Wang, J.; Zhang, T.; Mei, Y.; Pan, B. Treatment of reverse-osmosis concentrate of printing and dyeing wastewater by electro-oxidation process with controlled oxidation-reduction potential (ORP). Chemosphere 2018, 201, 621-626. [CrossRef]

49. Zazou, H.; Afanga, H.; Akhouairi, S.; Ouchtak, H.; Addi, A.A.; Akbour, R.A.; Assabbane, A.; Douch, J.; Elmchaouri, A.; Duplay, J. Treatment of textile industry wastewater by electrocoagulation coupled with electrochemical advanced oxidation process. J. Water Process Eng. 2019, 28, 214-221. [CrossRef]

50. Anipsitakis, G.P.; Dionysiou, D.D.; Gonzalez, M.A. Cobalt-mediated activation of peroxymonosulfate and sulfate radical attack on phenolic compounds. Implications of chloride ions. Environ. Sci. Technol. 2006, 40, 1000-1007. [CrossRef]

51. Sun, Y.; Zhao, J.; Zhang, B.-T.; Li, J.; Shi, Y.; Zhang, Y. Oxidative degradation of chloroxylenol in aqueous solution by thermally activated persulfate: Kinetics, mechanisms and toxicities. Chem. Eng. J. 2019, 368, 553-563. [CrossRef]

52. Fang, G.-D.; Dionysiou, D.D.; Wang, Y.; Al-Abed, S.R.; Zhou, D.-M. Sulfate radical-based degradation of polychlorinated biphenyls: Effects of chloride ion and reaction kinetics. J. Hazard. Mater. 2012, 227, $394-401$. [CrossRef]

53. Wang, Y.R.; Chu, W. Degradation of a xanthene dye by Fe(II)-mediated activation of Oxone process. J. Hazard. Mater. 2011, 186, 1455-1461. [CrossRef]

54. Rao, Y.; Shan, G.; Yang, X. Some recent advances in transition-metal-catalyzed ortho SP 2 CH functionalization using Ru, Rh, and Pd. Sci. China Chem. 2014, 57, 930-944. [CrossRef]

55. Pan, X.; Yan, L.; Qu, R.; Wang, Z. Degradation of the UV-filter benzophenone-3 in aqueous solution using persulfate activated by heat, metal ions and light. Chemosphere 2018, 196, 95-104. [CrossRef] [PubMed]

56. Weng, C.-H.; Tao, H. Highly efficient persulfate oxidation process activated with $\mathrm{Fe} 0$ aggregate for decolorization of reactive azo dye Remazol Golden Yellow. Arab. J. Chem. 2015. [CrossRef]

57. Nie, M.; Yang, Y.; Zhang, Z.; Yan, C.; Wang, X.; Li, H.; Dong, W. Degradation of chloramphenicol by thermally activated persulfate in aqueous solution. Chem. Eng. J. 2014, 246, 373-382. [CrossRef]

58. Su, S.; Cao, C.; Zhao, Y.; Dionysiou, D.D. Efficient transformation and elimination of roxarsone and its metabolites by a new $\alpha$-FeOOH@ GCA activating persulfate system under UV irradiation with subsequent As (V) recovery. Appl. Catal. B Environ. 2019, 245, 207-219. [CrossRef]

59. Han, D.; Wan, J.; Ma, Y.; Wang, Y.; Huang, M.; Chen, Y.; Li, D.; Guan, Z.; Li, Y. Enhanced decolorization of Orange $\mathrm{G}$ in a Fe (II)-EDDS activated persulfate process by accelerating the regeneration of ferrous iron with hydroxylamine. Chem. Eng. J. 2014, 256, 316-323. [CrossRef]

60. Lin, X.-m.; Ma, Y.-w.; Wang, Y.; Wan, J.-q.; Guan, Z.-y. Lithium iron phosphate (LiFePO 4) as an effective activator for degradation of organic dyes in water in the presence of persulfate. RSC Adv. 2015, 5, 94694-94701. [CrossRef]

61. Yadav, A.; Sharma, A.; Sharma, R.K. Mesoporous iron gallate nanocomplex for adsorption and degradation of organic dyes. Colloids Surf. A Physicochem. Eng. Asp. 2019, 579, 123694. [CrossRef]

62. Singh, S.; Pakshirajan, K. Enzyme activities and decolourization of single and mixed azo dyes by the white-rot fungus Phanerochaete chrysosporium. Int. Biodeterior. Biodegrad. 2010, 64, 146-150. [CrossRef]

63. Pakshirajan, K.; Jaiswal, S.; Das, R.K. Biodecolourization of Azo Dyes Using Phanerochaete Chrysosporium: Effect of Culture Conditions and Enzyme Activities. J. Sci. Ind. Res. 2011, 70, 987-991. 
64. Pakshirajan, K.; Singh, S. Decolorization of synthetic wastewater containing azo dyes in a batch-operated rotating biological contactor reactor with the immobilized fungus Phanerochaete chrysosporium. Ind. Eng. Chem. Res. 2010, 49, 7484-7487. [CrossRef]

65. Singh, S.; Pakshirajan, K.; Daverey, A. Screening and optimization of media constituents for decolourization of Mordant Blue-9 dye by Phanerochaete chrysosporium. Clean Technol. Environ. Policy 2010, 12, 313-323. [CrossRef]

66. Šimek, M.; Mikulášek, P.; Kalenda, P.; Weidlich, T. Possibilities for removal of chlorinated dye Mordant Blue 9 from model waste water. Chem. Pap. 2016, 70, 470-476. [CrossRef]

67. Tomić, N.a.M.; Dohčević-Mitrović, Z.D.; Paunović, N.M.; Mijin, D.a.Z.; Radić, N.D.; Grbić, B.k.V.; Aškrabić, S.M.; Babić, B.M.; Bajuk-Bogdanović, D.V. Nanocrystalline CeO2- $\delta$ as effective adsorbent of azo dyes. Langmuir 2014, 30, 11582-11590. [CrossRef] [PubMed]

(C) 2019 by the authors. Licensee MDPI, Basel, Switzerland. This article is an open access article distributed under the terms and conditions of the Creative Commons Attribution (CC BY) license (http://creativecommons.org/licenses/by/4.0/). 